УДК 004.89:620.9

DOI: 10.17277/vestnik.2019.03.pp.374-380

\title{
INTELLIGENT ENERGY-SAVING INDUCTION MOTOR CONTROL SYSTEM
}

\author{
S. V. Artemova ${ }^{1}$, A. A. Artemov ${ }^{2}$, N. G. Chernyshov ${ }^{3}$, M. A. Kamenskaya ${ }^{3}$ \\ Departments of Informatics (1), Higher Mathematics (2), \\ MIREA - Russian Technological University, SArtemova@yandex.ru; Moscow, Russia; \\ Department of Designing of Radio-Electronic and Microprocessor Systems (3), \\ Tambov State Technical University, Tambov, Russia
}

Keywords: induction motors; energy-saving control; intelligent system; method of synthesizing variables.

\begin{abstract}
The article discusses the application of intelligent system in energysaving control of induction motors. It presents description of controlling objects on a variety of operation states, mathematical formulation of the problem to be solved with the example and with technical realization of induction motor energy-saving control system.
\end{abstract}

\section{Introduction}

Induction of asynchronous motors due to their constructive simplicity, high reliability and low cost is widely used in industry and in household appliances.

In modern conditions the increased attention is paid to energy conservation. Development of intellectual control systems by criterion of energy-saving is an urgent task due to the widespread popularity of induction motors.

\section{Intellectualization in energy-saving control problem solving}

The intelligent energy-saving control system is understood as a set of technical, software and information assets, providing the solution to control analysis and synthesis tasks in dynamic operation modes of induction motors in real time without the participation of the decision maker.

Traditionally, dynamic regimes of induction motors are described by systems of differential equations. Getting their solutions in real scale is quite difficult. Therefore simplified engineering methods are often used in determining the basic parameters of the controlled process. But they have a large computation error which can lead to undesirable consequences. Therefore these methods are not desirable to use in solving the problems of real-time energy-saving control. However technology of modern artificial intelligence allows us to find a solution for the tasks of controlling such objects.

Intellectualization of the developed system lies in algorithmization of synthesizing control influences, minimizing power consumption of induction motors in real-time without the participation of the decision maker. Intellectualization is based on the following approaches:

- theory of system analysis and synthesis on a variety operation conditions [1]; 
- method of synthesizing variables for getting optimal control functions and their parameters; tasks.

- application of artificial intelligence methods for solving difficultly formalizable

Let us take a closer look at proposed approaches, used in newly developed intelligent energy-saving induction motors control system (IEIM CS).

The variety of operation states is expressed as Cartesian multiplication of induction motors operation states $H^{o t}$ and operability states $H^{o b}$. Factors, affecting operation states from $H^{o t}$ are divided on internal $H_{i}^{i n}, i=\overline{1, n}$, and external $\left(H^{p l}\right.$, $\left.H^{e x}\right): H^{p l}$ is power line voltage and frequency variations, $H^{e x}$ is environment changes. Thus, a variety of induction motors operation states can be expressed as $H^{o t}=H_{1}^{i n} \times \ldots \times H_{n}^{i n} \times H^{p l} \times H^{e x}$. The variety of operability states contains $H_{m p}$ as the most probable and $H_{c s}$ as critical states $\left\{H_{m p}, H_{c s}\right\} \subset H^{o b}$.

The values of the variable $h$, describing studied object operational states, are set as cortege $h=\left\langle h^{o t}, h^{o b}\right\rangle$, where $h^{o t} \in H^{o t}, \quad h^{e x} \in H^{e x}$. The condition change of $h$ takes place, when at least one component changes in cortege. The injection of operation states set during the development of IEIM CS is necessary for creating algorithms and software.

The use of synthesizing variables method allows finding the best form of control functions and their parameters during the development of IEIM CS. Synthesizing variables method allows to bring multidimensional problem of energysaving control to usage of two - three synthesizing variables, and also let us efficiently synthesize a solution to energy-saving problem without the participation of the decision maker on the whole set of functioning states.

Implementation of approaches described above allows solving energy-saving control problem by means of IEIM CS in conditions of uncertainty in real time without the participation of the decision maker.

\section{The mathematical formulation of the research problem}

The mathematical formulation of energy-saving control of induction motors acceleration dynamic modes in a generalized form can be presented by in the following way $[2,3]$. We specify:

- object dynamics models

$$
\dot{z}=f_{1}(A, B, z, u, t),
$$

where $A, B$ is a matrix of object model parameters, $z, u$ are phase coordinates and control influences vectors;

- restrictions to change phase coordinates, control influences and minimizing functional, i.e.

$$
\begin{gathered}
z\left(t_{0}\right)=z^{0} \rightarrow z\left(t_{k}\right)=z^{k} ; \\
\forall t \in\left[t_{0}, t_{k}\right]: u(t) \in\left[u_{\text {low }}, u_{\text {top }}\right] ; \\
J=\int_{t_{0}}^{t_{k}} u^{2} d t \rightarrow \min _{u} .
\end{gathered}
$$


where $z^{0}$ and $z^{k}$ are initial and final state of phase coordinates vector; $u_{\text {low }}$ and $u_{\text {top }}$ - lower and upper control limits; $t_{0}, t_{k}-$ start and end times; $J$ - minimizing functional;

- array of energy-saving control task parameters can be represented as follows:

$$
\mathfrak{R}=\left\{A, B, z_{0}, z_{k}, u_{\text {low }}, u_{\text {top }}, t_{0}, t_{k}, h\right\} .
$$

It is necessary to transfer the object, presented as model (1) from the initial state $z^{0}$ to the final $z^{k}$ during a fixed time interval when restriction to the control actions (3) with a minimum of functional (4).

To solve energy-saving control task(1) - (4) - is determine the type of control function $u(t), t \in\left[t_{0}, t_{k}\right]$ for a given array $\mathfrak{R}$, calculate its parameters, determine the optimal trajectory of phase coordinates alterations $z^{*}(t)$ and the value of the functional $J$.

\section{Solving the energy-saving control problem of induction motors}

We solve the following problem. We have a three phase squirrel cage induction motor which operating rotation frequency is $2850 \mathrm{rpm}$, the number of impeller blades is 31 , the static mode release time is $370 \mathrm{~ms}$, sampling interval is $20 \mathrm{~ms}$. The acceleration curve is shown in Fig. 1.

Using dynamics model identity module, data and knowledge bases of IEIM CS, we get a differential equation as the dynamics model, which is relevant to inertial object of the first order

$$
\dot{z}=a z(t)+b u(t) .
$$

It does not contradict with (1) - (4). The model parameters in IEIM CS are determined by experimental data (Fig. 1), and according to the following formulas:

$$
\hat{a}_{i}=\frac{1}{\Delta t} \ln c_{i} ; \quad b_{i}=\frac{d_{i} \hat{a}_{i}}{c_{i}-1} ;
$$

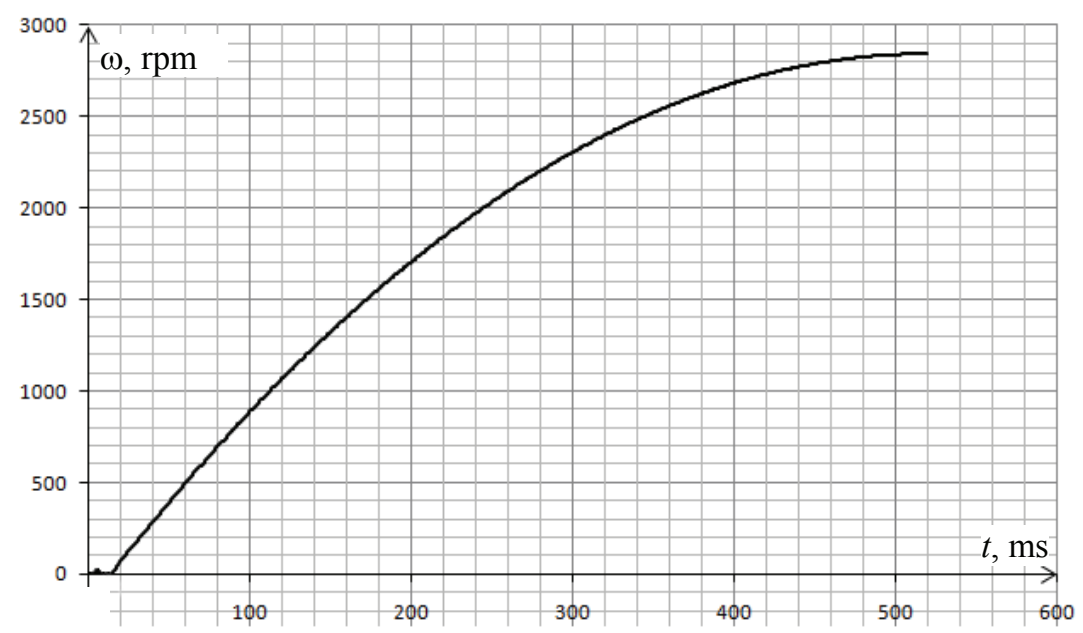

Fig. 1. Motor acceleration curve 


$$
\begin{gathered}
c_{i}=\frac{y\left(t_{i}\right) u\left(t_{i}\right)-y\left(t_{i+1}\right) u\left(t_{i-1}\right)}{\Delta_{i}} ; \\
d_{i}=\frac{y\left(t_{i+1}\right) y\left(t_{i-1}\right)-y^{2}\left(t_{i}\right)}{\Delta_{i}} ; \\
\Delta_{i}=y\left(t_{i-1}\right) u\left(t_{i}\right)-y\left(t_{i}\right) u\left(t_{i-1}\right),
\end{gathered}
$$

the minimum time interval of calculation is equal to $2 \Delta t$, i.e. $\left[t_{0} ; t_{k}\right]=\left[t_{i-1} ; t_{i+1}\right]$.

An array of energy-saving control problem parameters has the following form

$R=\left(a=-0.0025, b=0.033, u_{0}=0, u_{\text {top }}=380, t_{0}=50, t_{k}=400, z^{0}=0, z^{k}=3000\right)$.

This data comes in the analysis and intelligent synthesis module of solving energysaving control problem. As a result, we have synthesized optimal program of energysaving control, having this form:

$$
u_{7}(t)=\left\{\begin{array}{l}
115,176 \mathrm{e}^{-0,00209\left(t-t_{0}\right)}+u_{0}, t \in\left[t_{0}, 289,21\right), \\
u_{t o p}, t \in\left[289,21, t_{k}\right] .
\end{array}\right.
$$

Figure 2 shows the analysis and intelligent synthesis module graphical interface. There you can see the control task parameters, synthesizing variables flat on the whole set of functioning states, energy-saving control function calculated by obtained program and the trajectory of phase coordinates alterations calculated according to the received program, as well as the value of calculated energy costs functional.

The IEIM CS block diagram is shown in Fig. 3. Based on the requirements to performance and complexity of processes, controlled by the IEIM CS, industrial controller WinCon I-8737G was selected as the main element on the controlled object.

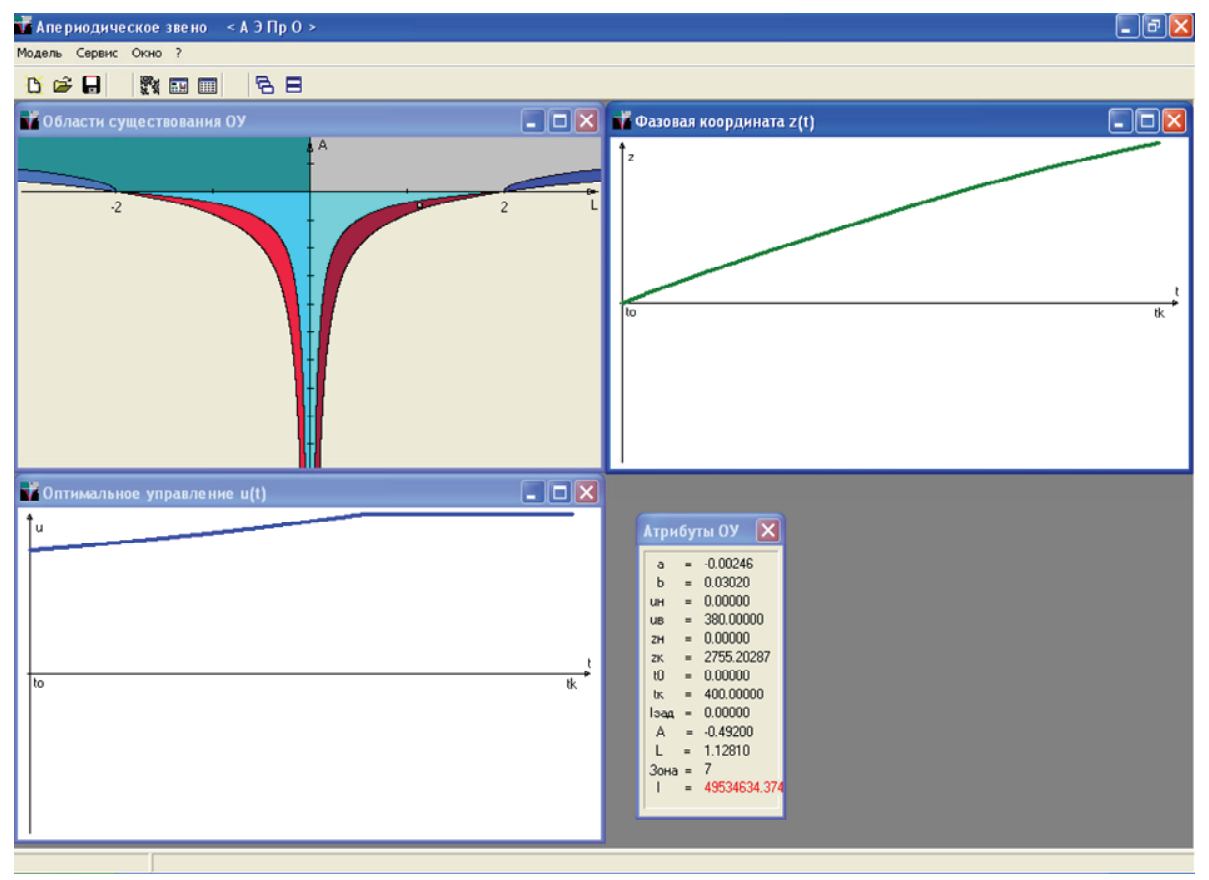

Fig. 2. Analysis and intelligent synthesis module graphical interface 


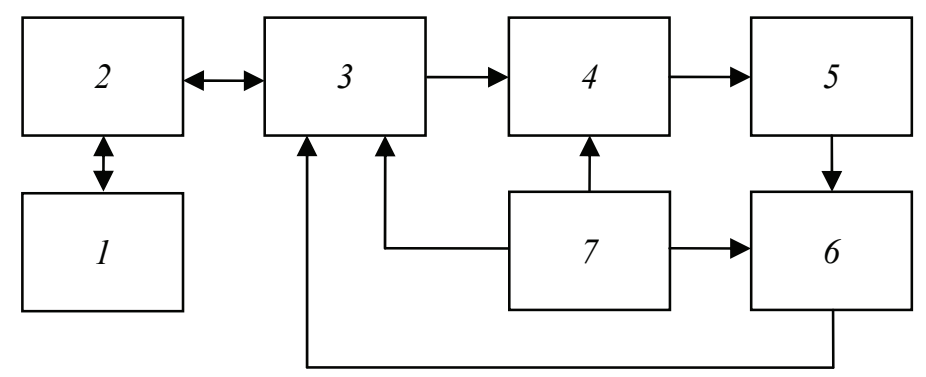

Fig. 3. IEIM CS block diagram

Access to data and knowledge bases of IEIM CS was performed by intellectualized interface, having multiple inputs with different access levels for cognitive science engineers, experts, programmers and the system operator. Intellectualized interface 1 was connected to programmable controller 3 through router 2 via the Internet. The connection of programmable controller and router was provided by the Ethernet technology and TCP/IP network protocols.

Within the system the router performed the control system access functions both from local network and remote intellectualized interface, as well as unauthorized access protection through the creation of secure VPN-channel between intellectualized interface and router. This communication channel was used to collect the telemetry data by a developer, export control program and its debugging. It should be noted, that the operator presence at the site was no longer necessary under any status changes after completion of telemetry and debugging procedures.

Motor 5 control was carried by multi-channel digital output module 4 (I7045) managed by the programmable controller 3. Actuating devices were made on optosimistors with zero potential detection circuit. Hall sensors were used to monitor rotor rotation speed. The signal from the sensors is converted by multi-channel analog input module 6 (i-7017) and processed by programmable controller 3 .

Programmable controller and input-output modules connection was performed through RS-485 interface using a communication protocol DCON. Control system power supply was performed by energy module 7 (ACE-540A).

The results of the solution of the induction motors energy-saving control problem and energy-saving control system were widely implemented on JSC "Pigment" (Tambov). Due to this control system the energy saving has reached $13.93 \%$. It should be noted that this approach has high versatility for building energy-saving control intelligent systems and can be used for other facilities.

The research was supported by the Russian Ministry of Science and Higher Education (Project "Intelligent information-measuring and control system of operational control of thermal characteristics of thermal insulation materials used in the Arctic. Development of theoretical foundations, methodology of intelligent information-measuring and control systems")

\section{References}

1. Muromtsev Yu.L., Orlova L.P., Chernishov N.G. Mathematical and Software of Microprocessor-Based Energy-Saving Control Systems, Automatics and Computer Engineering, 1996, no. 6, pp. 26-34.

2. Chernishov N.G., Artemova S.V. Energy-Saving Control System of EnergyIntensive Objects Heating Processes, Automatics and Computer Engineering, 2001, no. 3, pp. 25-33. 
3. Chernishov N.G., Muromtsev D.Yu. Peculiarities of Energy-Saving Control System Creation on a Variety of Operation States, Automatics and Computer Engineering, 2008, no. 3, pp. 74-82.

4. Chilikin M.G., Kluchev V.I., Sandler A.S. Automated Electric Drive Theory: Textbook for Universities, Moscow: Energy, 1979, 616 p. (In Russ.)

5. Smirnova V.I., Razintsev V.I. Automatic Drive Design and Engineering, Moscow: Engineering, 1990, 368 p. (In Russ.)

6. Yaure A.G., Bogoslovskye A.P., Pevzner E.M. [et al.] Modern State and Tendencies of Thyristor AC Drives, Moscow: Informelectro, 1981, 52 p. (In Russ.)

7. Fainshtein V.G., Fainshtein E.G., Snejansky O.V. [Ed.] Microprocessor Thyristor Motor Control System, Moscow: Energoatomisdat, 1986, 240 p. (In Russ.)

\title{
Интеллектуальная система энергосберегающего управления асинхронными двигателями
}

\author{
С. В. Артемова ${ }^{1}$, А. А. Артемов ${ }^{2}$, Н. Г. Чернышов ${ }^{3}$, М. А. Каменская ${ }^{3}$ \\ Кафедры: информатики (1), выстей математики (2), \\ ФГБОУ ВО «МИРЭА - Российский технологический университет», \\ SArtemova@yandex.ru; г. Москва, Россия; \\ кафедра «Конструирование радиоэлектронных \\ и микропроиессорных систем» (3), ФГБОУ ВО «ТГТУ», г. Тамбов, Россия
}

Ключевые слова: асинхронные двигатели, энергосберегающее управление, интеллектуальная система, метод синтеза переменных.

Аннотация: Рассмотрено применение интеллектуальной системы в энергосберегающем управлении асинхронными двигателями. Представлено описание объектов управления в различных рабочих состояниях, математическая постановка задачи, решаемой на примере и с технической реализацией энергосберегающей системы управления асинхронным двигателем.

\section{Список литературы}

1. Муромцев, Ю. Л. Математическое и программное обеспечение микропроцессорных систем энергосбережения / Ю. Л. Муромцев, Л. П. Орлова, Н. Г. Чернышов // Автоматика и вычислительная техника. - 1996. - № 6. - С. 26 - 34 .

2. Чернышов, Н. Г. Система энергосберегающего управления процессами нагрева энергоемких объектов / Н. Г. Чернышов, С. В. Артемова // Автоматика и вычислительная техника. - 2001. - № 3. - С. 25 - 33.

3. Чернышов, Н. Г. Особенности создания систем энергосберегающего управления на множестве состояний функционирования / Н. Г. Чернышов, Д. Ю. Муромцев // Автоматика и вычислительная техника. - 2008. - № 3. - С. $74-82$.

4. Чиликин, М. Г. Теория автоматического электропривода : учеб. пособие для вузов / М. Г. Чиликин, В. И. Ключев, А. С. Сандлер. - М. : Энергия, 1979. $616 \mathrm{c}$.

5. Смирнова, В. И. Проектирование и расчет автоматизированных приводов / В. И. Смирнова, В. И. Разинцев. - М. : Машиностроение, 1990. - 368 с.

6. Современное состояние и тенденции развития тиристорных электроприводов переменного тока для краново-подъемных механизмов / А. Г. Яуре, А. П. Богословский, Е. М. Певзнер [и др.]. - М. : Информэлектро, 1981. - 52 с. 
7. Файнштейн, В. Г. Микропроцессорные системы управления тиристорными электроприводами / В. Г. Файнштейн, Е. Г. Файнштейн ; под ред. О. В. Слежановского. - М. : Энергоатомиздат, 1986. - 240 с.

\section{Intellektuelles Energiesparsteuerungssystem von Asynchronmotoren}

Zusammenfassung: Es ist die Anwendung des intellektuellen Systems in der energiesparenden Steuerung von Asynchronmotoren betrachtet. Die Beschreibung der Steuerobjekte in verschiedenen Betriebszuständen, die mathematische Formulierung der Aufgabe, die am Beispiel und mit der technischen Umsetzung des energiesparenden Steuerungssystems des asynchronen Motors gelöst wird, ist vorgestellt.

\section{Système intelligent de la commande économisant de l'énergie des moteurs asynchrones}

Résumé: Est considérée l'application du système intelligent de la commande économisant de l'énergie des moteurs asynchrones. Sont présentées la description des objets de la commande dans divers états de travail, la mise mathématique de la tâche résolue à l'exemple du système intelligent de la commande économisant de l'énergie du moteur asynchrone.

Авторы: Артемова Светлана Валерьевна - доктор технических наук, профессор кафедры информатики; Артемов Анатолий Анатольевич - доктор физико-математических наук, профессор кафедры высшей математики, ФГБОУ ВО «МИРЭА - Российский технологический университет», г. Москва, Россия; Чернышов Николай Генрихович - кандидат технических наук, доцент, заведующий кафедрой «Конструирование радиоэлектронных и микропроцессорных систем»; Каменская Мария Анатольевна - кандидат технических наук, ассистент кафедры «Конструирование радиоэлектронных и микропроцессорных систем», ФГБОУ ВО «ТГТУ», г. Тамбов, Россия.

Рецензент: Павлов Владимир Иванович - доктор технических наук, профессор кафедры «Конструирование радиоэлектронных и микропроцессорных систем», ФГБОУ ВО «ТГТУ», г. Тамбов, Россия. 